\title{
TRAF2 wt Allele
}

National Cancer Institute

\section{Source}

National Cancer Institute. TRAF2 wt Allele. NCI Thesaurus. Code C52445.

Human TRAF2 wild-type allele is located in the vicinity of 9q34 and is approximately $40 \mathrm{~kb}$ in length. This allele, which encodes TNF receptor-associated factor 2 protein, is involved in the progression of tumor necrosis factor-alpha stimulated signaling. 